\title{
The effects of implementing ISO 9001 in the Spanish construction industry
}

\section{Los resultados de la implantación de la Normativa ISO 9001 en el sector de la construcción español}

\author{
Camilo Prado-Roman ${ }^{1}$ \\ Carlos Del Castillo-Peces ${ }^{1}$ \\ Carmelo Mercado-Idoeta ${ }^{1}$ \\ Julian Del Castillo-Peces ${ }^{1}$ \\ Universidad Rey Juan Carlos (España)
}

Recibido el 1 de noviembre de 2014, aceptado el 9 de julio de 2015

Publicado online el 4 de mayo de 2016

$\mathrm{N}^{\circ}$ de clasificación JEL: L15, M10

DOI: $10.5295 / \mathrm{cdg} .140507 \mathrm{~cd}$

\begin{abstract}
:
The ISO 9001 Standard - a quality assurance standard for products and services - is well established in the construction industry, which is one of the major industries in the world, including Spain. The objectives of this paper are, on the one hand, to analyse the results of adhering to this standard for construction companies in Spain, and on the other, to examine whether these results are affected by the size of the organization and the seniority of the certification. To this end, a questionnaire was sent to quality managers of 302 companies in the industry, and the responses of 126 valid questionnaires received were treated by descriptive analysis and ANOVA. From the answers gathered is concluded that obtaining the ISO 9001 certification has positive effects leading to benefits which are both "internal" and "external". Some of the most significant internal benefits mentioned were improvements to the organisational processes, while among the external benefits, commercial aspects, such as better chances of competing on the market, were mentioned most frequently. It was also observed that the size of the organization does not significantly modify the positive effects of adherence to the standard, while the age of the certification itself, has a significant influence on the positive results of the adherence.
\end{abstract}

\section{Keywords:}

Quality management. quality assurance standards, ISO 9001 standard, construction industry.

\section{Resumen:}

El sector de la construcción es uno de los más importantes tanto a nivel mundial como español, y presenta una amplia implantación de la Norma ISO 9001 como norma de aseguramiento de la calidad de sus productos y servicios. Los objetivos del presente trabajo son, por un lado, analizar los resultados derivados de la adhesión a dicha Norma por parte de las empresas del sector de la construcción español, y por otro, verificar si dichos

\footnotetext{
${ }^{1}$ Departamento de Economía de la Empresa. Facultad de Ciencias Jurídicas y Sociales, Paseo de los Artilleros S/N,28032 Madrid (España).camilo.prado.roman@urjc.es; carlos.delcastillo@urjc.es; carmelo.mercado@urjc.es; julian.delcastillo,peces@urjc.es
} 
resultados están influenciados por el tamaño de dichas empresas y la antigüedad de la certificación. Para ello se ha remitido un cuestionario a los directores de calidad de 302 empresas de dicho sector, recibiéndose 126 cuestionarios válidos, cuyas respuestas fueron tratadas mediante un análisis descriptivo y ANOVA. De las respuestas recogidas se concluye que la implantación de ISO 9001 tiene una influencia positiva para la obtención de beneficios tanto de índole "interna" como "externa". Dentro de los beneficios "internos", destacan las mejoras organizativas, mientras que en lo relativo a los "externos" destacan los aspectos comerciales, es decir, la posibilidad de competir en el mercado. Así mismo, se verifica que el tamaño de las empresas no provoca diferencias significativas en la influencia positiva de la adhesión a la Norma, mientras que la antigüedad de la certificación sí influye de forma significativa en los resultados positivos de dicha adhesión.

\section{Palabras clave:}

Gestión de calidad, normas aseguramiento de la calidad, norma ISO 9001, sector construcción. 


\section{INTRODUCTION}

Today, delivering services or products that outperform those offered by the competition represents a key factor for firms to gain competitive advantage (Martínez et al. 2010). To achieve this quality, firms must implement quality management systems, which provide management tools to establish policies and duties, allocate resources, and identify key activities (Criado and Calvo 2009).

This need to control quality management in firms has led to the emergence of quality management standards, with the ISO 9000 standards becoming the most widespread. These standards, which were created in 1987, often represent a firm's first experience of quality management (Martinez et al. 2004). Firms around the world have embraced these standards to such an extent that by the end of 2012, there were 1,096,987 certified firms worldwide, 469,739 certified firms in Europe and 59,418 certified firms in Spain (ISO 2013).

The construction sector is one of the most important sectors worldwide, representing $11 \%$ of 2011 global GDP and projected to account for $13.2 \%$ of global GDP by $2020^{2}$. The construction sector is also one of the most important sectors of the Spanish economy. According to Seopan (2012), construction represented 10.5\% of Spain's 2011 GDP and accounted for $8 \%$ of employment in Spain in 2011 (1.37 million employees). At the height of the boom in the previous economic cycle (2006), construction represented $12.6 \%$ of Spain's GDP and accounted for 13.9\% of employment in Spain (2.7 million employees).

This sector has been one of the most heavily affected by fierce competition. Accordingly, sound quality management has become a key tool for building customer loyalty, which is fundamental given the importance of safety in all products and services offered by the construction sector (FLC 2002). In addition to the fierce competition within the sector, the current recession in Spain has hit this sector particularly hard, forcing firms to expand to foreign markets as a means of survival. A key condition of this expansion is that firms meet international quality standards (Torres 2009).

This situation has led to the widespread implementation of ISO 9001 in the construction sector. In terms of numbers of certified firms, the construction sector is the second sector worldwide, and the first sector in Spain, with 7,856 certified firms (ISO 2013). As with total quality management models, the initial application and maintenance of ISO 9001 means allocating resources and accounting for the costs involved, so the motivation to implement ISO 9001 must be justified by some reward that makes the cost worthwhile. These rewards may be 'internal' and/or 'external' (Sampaio et al. 2010; Heras et al. 2010).

This paper assesses the positive effects of implementing ISO 9001 in the Spanish construction sector, focusing on civil engineering firms. The paper examines whether these effects vary with the size of the firm and the time elapsed since the firm obtained the standard. A postal questionnaire sent to heads of quality in 302 firms yielded 126 valid responses. Results and discussion of the analysis of these data appear in sections 4 and 5.

2 See Global Construction 2020: Global Construction Perspectives and Oxford Economics. (www. globalconstruction2020.com) 


\section{LITERATURE REVIEW}

Today, firms operate in competitive, globalised environments. To survive, firms must achieve their goals as efficiently as possible whilst focusing on the customer. This forces firms to introduce management systems that allow them to establish policies and duties, allocate resources, and identify and perform key activities. The most common management systems are quality management systems (Martínez et al. 2004; Criado and Calvo 2009). Quality management systems encompass quality assurance standards, the most widespread examples of which are the ISO 9000 standards, created in 1987. Such standards are usually based on qualitative quality tools that require little knowledge and experience of quality (Casadesus et al. 2011). Accordingly, the use of these tools has spread rapidly across many sectors worldwide, including the Spanish construction sector (ISO 2013).

The implementation of the ISO 9000 standards requires an initial and ongoing investment of money, time and organisational resources (Pires et al. 2013). Therefore, the motivation to implement the ISO 9000 standards must be linked to maximising returns through different types of direct or indirect benefits to the firm (Magd 2008; Sampaio et al. 2010; Heras et al. 2010; Rusjan and Alic 2010; Alic 2014). Nonetheless, these investments do not always yield benefits (Psomas 2013). In fact, they may even have negative effects - such as an increase in bureaucracy and workload - that sometimes outweigh the rewards (Delic et al.2014). Studies have specifically analysed the results of implementing these standards, although assessing the effects of quality initiatives is difficult because few firms are able to isolate these effects or quantify them (Mann and Kehoe 1994). Nevertheless, numerous studies have analysed the consequences of implementing ISO 9000 standards, albeit with considerable difficulty and discrepancies in their findings.

\subsection{Positive effects of implementing the ISO 9001}

Most researchers have concluded that ISO 9001 yields positive benefits for firms. A small number of studies, however, do not report these positive effects, at least not in all cases or circumstances (Heras et al. 2002; Wilson et al. 2003; Martínez-Costa and Martínez-Lorente 2007; Martínez-Costa et al. 2009; Boiral and Amara 2009; Delic et al. 2014). These studies have consistently shown that it is not enough to formally implement ISO 9001 simply to follow the trend or boost the firm's image. The standard must be effectively implemented in parallel with the internal development of basic quality management principles such as the systematisation of processes, continuous improvement, involvement of the entire firm and customer focus.

Several studies (Escanciano et al. 2001; Gotzamani and Tsiotras, 2002; Douglas et al. 2003; Casadesus et al. 2004; Lo et al. 2009; Wahid and Corner, 2009; Sampaio et al. 2009 and 2010; Gutiérrez et al. 2010; Tari et al. 2012), have classified the positive outcomes from implementing ISO 9001 in two groups: internal aspects (organisational processes, operations and human resources management) and external aspects (commercial and financial performance and customer management). Some studies have emphasised the importance of internal aspects (Williams 2004; Climent 2005; Bhuyam and Alam 2005; Bayati and Taghavi 2007; Terziovsky and Power 2007; Martinez-Costa et al. 2008; Lo et al. 
2009; Wahid and Corner 2009; Heras et al. 2011; Melao and Guia 2013), whereas other studies have stressed the importance of external aspects (Wayhan et al. 2002; Nicolau and Sellers 2003; Corbett et al. 2005; Sharma 2005; Terlaak and King 2006; Martínez-Costa and Martínez-Lorente 2007; Vinuesa 2007; Benner and Veloso 2008; Dick et al. 2008; Karapetrovic et al. 2010). Regardless, most studies have reported positive results for both internal and external aspects (Escanciano et al. 2001; Gotzamani and Tsiotras 2002; Casadesús et al. 2004; Mercado et al. 2005; Rodriguez et al. 2006; Calisir 2007; Lo and Chang 2007; Zaramdini 2007; Feng et al. 2008; Jang and Lin 2008; Magd et al. 2010). Tari et al. (2012) reviewed 82 studies on the benefits of ISO 9001, reporting that the most commonly cited positive effects were internal aspects related to operations and human resources and external aspects related to the customer.

In general, these studies show that the type of benefit sought (internal vs. external) when deciding to implement ISO 9001 strongly influences the type of positive effects the firm actually achieves. For example, if the firm prioritises external benefits such as meeting requirements or standards demanded by customers or the competition with no intention of actually improving the firm's quality, the external benefits of becoming more competitive will be more pronounced and may be the only benefits the firm achieves. In contrast, if the firm has at least the same desire to improve internal aspects as to improve external aspects, the positive effects of implementing ISO 9001 will first be internal and then external. These studies also show that regardless of the predominant type of motivation, implementing the standard must be thorough and not merely superficial - that is to say, the standard must be implemented along with the development of the aforementioned basic principles of processes systematisation, continuous improvement, involvement of the entire firm, customer focus and so forth.

In construction in general, and in civil service construction in particular, both internal and external motivations seem a priori to exist. On the one hand, civil service construction depends on winning public tenders, where holding ISO 9001 is a pre-requisite. On the other hand, the safety of civil engineering projects is fundamental, so firms are keen to eliminate errors and meet deadlines to avoid hefty fines and sanctions. It is therefore reasonable to expect firms to achieve internal and external benefits, hence the following hypothesis:

Hypothesis 1: Implementing ISO 9001 in the construction sector yields both internal and external benefits in most cases.

\subsection{Influence of the size of the firm on the positive effects of implementing ISO 9001}

Research has been inconclusive regarding the influence of firm size on the benefits of implementing ISO 9001. Studies have indicated that small enterprises are less likely to benefit from ISO 9001 because they usually lack key internal resources to ensure successful implementation, at least in terms of achieving internal benefits. Furthermore, the cost of the initial investment required to obtain the standard are proportionally higher in small firms than in large firms (Nwankwo 2000; Gustafsson et al. 2001; Rodriguez et al. 2006). In contrast, several authors have reported that benefits are similar across all firms, regardless of their size, arguing that attainment of the standard depends more on the intensity with which the firm implements the standard than on contextual variables such as size. Nevertheless, 
small firms may take longer to obtain the standard (Terziovski et al. 2003; Wilson et al. 2003; Briscoe et al. 2005; Bayati and Taghavi 2007; Lee et al. 2009; Psomas et al. 2010). In fact, the benefits for small firms may actually be greater than for large firms because small firms' quality management is usually worse than that of large firms, which means that the potential for improvement is greater (Gotzamani and Tsiotras 2002). Regardless of their size, all firms in the construction sector need ISO 9001 to compete for tenders and meet the strict safety standards imposed upon firms in this sector. Hence, we formulate the following hypothesis:

Hypothesis 2: The size of construction firms is irrelevant in obtaining the internal and external benefits of implementing ISO 9001.

\subsection{Influence of time elapsed since the implementation of ISO 9001 on the positive effects of this implementation}

The literature is once again inconclusive as to the influence of the time since the firm began implementing ISO 9001 on the positive effects of this implementation. Most studies have shown that time is a positive factor for the appearance of benefits due to implementing ISO 9001 (Wilson et al. 2003; Climent 2005; Corbett et al. 2005; Terziovski and Power 2007; Martínez- Costa et al. 2008; Lo et al. 2009). Nevertheless, some studies have shown that time has no influence, at least not in all cases (Terziovski et al. 2003; Gotzamani et al. 2006; Lee et al. 2009), and may even lead to a reduction in the initial benefits from implementing ISO 9001 (Casadesús et al. 2004; Sampaio, Saraiva and Rodrigues 2009; Karapetrovic, Fa and Heras 2010). These findings suggest that the influence of time may vary depending on the sector and type of effect (i.e., internal vs. external). If the aim is to obtain certification to compete in the market, this benefit appears immediately, so time has no influence. If, on the other hand, the firm seeks internal benefits, the firm must wait for these benefits to become assimilated by the firm, so time does influence positive effects. Construction firms are driven by external motivations (meeting requirements to enter public tenders) and internal motivations (ensuring high quality standards that guarantee safety and prevent mistakes). Hence, we formulate the following hypothesis:

Hypothesis 3: The time elapsed since implementing ISO 9001 affects Spanish construction firms' ability to obtain external and internal benefits due to implementing ISO 9001.

\section{EMPIRICAL STUDY}

\subsection{Research aims}

The first aim of this study was to analyse the effects derived from implementing ISO 9001 in Spanish construction firms. Therefore it has been sought to determine whether, as reported by most scholars, these firms benefited from implementing ISO 9001. Furthermore, if ISO 9001 did indeed yield benefits, it has been tested whether internal or external benefits were greater. The second aim of the study was to analyse whether the size of Spanish construction firms and the time elapsed since obtaining ISO 9001 influenced the standard's effects. 


\subsection{Sample}

The study examined firms in the Spanish construction sector. Specifically, they have been analyzed firms that performed any kind of activity related to civil engineering. Civil engineering firms were chosen because the civil engineering cycle is more stable than that of building construction. Thereby it has been avoided any bias due to the stage of the cycle firms were in at the time of the study.

To identify the target population and determine the number of firms in this population, it has been used the NACE (National Classification of Economic Activities) classification, selecting all activities from the two-digit code 42 ('Civil engineering') and three-digit code 43.1 ('Specialised construction activities: Demolition and site preparation'). The three-digit code 43.1 captures auxiliary activities necessary for the completion of civil engineering projects. Choosing these sections and sub-sections yielded a census of 3,493 firms.

From this census, the firms have been segmented according to size based on the criteria set forth in the EU Commission Recommendation 2003/361/CE. Small firms (3,191 firms) have been eliminated because these firms were assumed to have a low degree of implementation of ISO 9001. This was confirmed by a telephone interview with 150 of these firms. Finally, within the group of large firms, a group of very large firms was created. Very large firms were defined as firms with more than 1,000 employees (Martín and González 2011). Due to their size, these firms have different operations and business models from other firms. Very large firms have greater resources to implement the processes and culture of a quality system, regardless of whether they hold ISO 9001. In addition, because of their high legitimacy within the market, these very large firms need the support afforded by external standards to secure business from customers less than smaller firms do. Hence, these very large firms have been analyzed separately. The final population consisted of 302 firms (12 very large firms, 63 large firms and 227 medium-sized firms).

\subsection{Method}

To obtain the necessary data for this study, two sources of primary information have been used. The data collection instrument was a questionnaire sent to the heads of quality within each firm. The questionnaire yielded data on quality managers' opinions regarding the positive effects of implementing ISO 9001. Therefore, it has not been sought to observe a causal relationship between the requirements of ISO 9001 and the outcomes of implementing this standard. Identification of such a relationship should be the aim of future studies.

The questionnaire built upon questionnaires used in other studies on this type of standard (Casadesús and Heras 2001; Escanciano et al. 2001; Casadesús et al. 2004; Arana et al. 2004; Mercado et al. 2005). A pre-test was performed with two firms from the sector. The final draft of the questionnaire included feedback from the pre-test. Appendix 1 shows the questionnaire used in this study. Table 1 shows the different types of positive effects as per the research discussed in section 2 - covered by the questionnaire. 
Table 1

Type of positive effects derived from implementing ISO 9001

\begin{tabular}{|c|c|}
\hline \multicolumn{2}{|r|}{ INTERNAL ASPECTS } \\
\hline Organisational processes & $\begin{array}{l}\text { Controlling production management, establishing rules and respon- } \\
\text { sibilities, improving coordination with suppliers, increasing innova- } \\
\text { tion, improving the IT systems for process management, improving } \\
\text { internal controls for detecting nonconformities, etc. }\end{array}$ \\
\hline Operations & $\begin{array}{l}\text { Better use of resources, reduction in inspection costs, improvements } \\
\text { in general efficiency, reduction in logistics costs and production costs, } \\
\text { reduction in nonconformities, improvements in meeting deadlines, } \\
\text { reduction in expenses due to poor quality, etc. }\end{array}$ \\
\hline $\begin{array}{l}\text { Human resources mana- } \\
\text { gement }\end{array}$ & $\begin{array}{l}\text { Improvements in employee feedback systems, participation in teams, } \\
\text { reduction in worker absenteeism, greater satisfaction and motivation } \\
\text { at work, etc. }\end{array}$ \\
\hline \multicolumn{2}{|r|}{ EXTERNAL ASPECTS } \\
\hline Commercial & Requirement to compete in the sector and enter new markets. \\
\hline Financial & $\begin{array}{l}\text { Increase in turnover and market share, improvements in turnover per } \\
\text { employee, etc. }\end{array}$ \\
\hline Customer management & $\begin{array}{l}\text { Increase in the number of contracts from the same clients, reduction } \\
\text { in nonconformities or complaints, improvements in satisfaction, } \\
\text { improvements in market image, etc. }\end{array}$ \\
\hline
\end{tabular}

Source: Own elaboration.

Respondents chose one of five options to reflect the relevance of ISO 9001 in causing each of the aforementioned positive effects. The options were 1) 'irrelevant', 2) 'slightly relevant', 3) 'moderately relevant', 4) 'highly relevant' and 5) 'extremely relevant'. A first wave of the questionnaire was sent in November 2011, and a second wave was sent in February 2012 to increase the number of returned questionnaires. Questionnaires were posted to respondents in all cases and sent via email if the email contact details were available in the databases used in this study. 126 complete questionnaires were received. The distribution of the size of the responding firms appears in Table 2. The data were gathered in April 2012 and were subsequently processed and analysed.

Table 2

Classification of the population and responses by size of firm

\begin{tabular}{|c|c|c|c|c|}
\hline SIZE & $\mathrm{N}^{\circ}$ & $\%$ S/ TOTAL & RESPONSES & $\begin{array}{c}\% \mathrm{~S} / \\
\text { POPULATION }\end{array}$ \\
\hline Very large firms & 12 & $3.97 \%$ & 10 & $83.33 \%$ \\
\hline
\end{tabular}




\begin{tabular}{|c|c|c|c|c|}
\hline Large firms & 63 & $20.86 \%$ & 30 & $47.62 \%$ \\
\hline Medium-sized firms & 227 & $75.17 \%$ & 86 & $37.89 \%$ \\
\hline TOTAL & 302 & $100 \%$ & 126 & $41.72 \%$ \\
\hline
\end{tabular}

Source: Own elaboration.

All responding firms held the ISO 9001 . In $68 \%$ of firms, the time elapsed since obtaining ISO 9001 was more than five years. In $93 \%$ of the responses, the firms had obtained the ISO 9001 for all of the firm's processes, a fact that adds weight to this study's conclusions. Table 3 shows the technical datasheet for the study.

Table 3

Technical datasheet for the study

\begin{tabular}{|l|l|}
\hline Population universe & $\begin{array}{l}\text { Spanish construction firms with a presence in the civil engineering sub- } \\
\text { sector, excluding small firms (as per EU Commission Recommendation } \\
\text { 2003/361/CE) }\end{array}$ \\
\hline Sampling method & Random: questionnaire sent to all entities in the population universe \\
\hline Data collection method & Postal and online \\
\hline Interviewee & Head of quality within the firm \\
\hline Population & 302 \\
\hline Sample size & $126($ response rate: $41.72 \%$ of the population) \\
\hline Confidence level & $95 \%(\mathrm{z}=1.96 ; \mathrm{p}=\mathrm{q}=0.5)$ \\
\hline Sampling error & $6.7 \%$ \\
\hline Date of data collection & From 1 November 2011 to 31 March 2012 \\
\hline
\end{tabular}

Source: Own elaboration.

\section{RESULTS}

\subsection{Positive effects derived from the implementation of ISO 9001 in Spanish con- struction firms}

The first aim of this study was to analyse the results derived from the implementation of ISO 9001 in Spanish construction firms. Accordingly, Table 4 shows the results regarding internal positive effects, and Table 5 shows the results regarding external positive effects. Tables 4 and 5 display the percentage of firms that chose each degree of relevance regarding the influence of ISO 9001 on each positive internal and external effect. These percentages highlight the relative importance of each factor. 
Table 4

Internal positive effects derived from the implementation of ISO 9001

\begin{tabular}{|c|c|c|c|}
\hline Internal effects & $\begin{array}{c}\text { Organisational } \\
\text { processes }\end{array}$ & Operations & Human resources management \\
\hline Irrelevant & 0.00 & 1.22 & 2.44 \\
\hline Slightly relevant & 4.88 & 6.10 & 20.73 \\
\hline Moderately relevant & 20.73 & 39.02 & 45.12 \\
\hline Highly relevant & 58.54 & 42.68 & 29.27 \\
\hline Extremely relevant & 15.85 & 10.98 & 2.44 \\
\hline TOTAL & $100 \%$ & $100 \%$ & $100 \%$ \\
\hline
\end{tabular}

Source: Own elaboration.

Table 4 shows that for $74.4 \%$ of surveyed firms, ISO 9001 was 'highly relevant' or 'extremely relevant' for internal positive effects related to organisational processes. The percentage of firms reporting that ISO 9001 was 'highly relevant' or 'extremely relevant' for internal positive effects related to operations was lower (53.7\%). Respondents gave the lowest score to the influence of ISO 9001 on internal aspects related to human resources management (only $31.7 \%$ of respondents reported that ISO 9001 was 'highly relevant' or 'extremely relevant'). For all types of internal effect, the percentage of firms choosing 'highly relevant' was notably higher than the percentage of firms choosing 'extremely relevant'.

Table 5

External positive effects derived from the implementation of ISO 9001

\begin{tabular}{|c|c|c|c|}
\hline External effects & Commercial & Financial & Customer management \\
\hline Irrelevant & 0.00 & 4.88 & 0.00 \\
\hline
\end{tabular}




\begin{tabular}{|c|c|c|c|}
\hline Slightly relevant & 4.88 & 20.73 & 2.44 \\
\hline Moderately relevant & 8.54 & 40.24 & 35.37 \\
\hline Highly relevant & 42.68 & 24.39 & 41.46 \\
\hline Extremely relevant & 43.90 & 9.76 & 20.73 \\
\hline TOTAL & $100 \%$ & $100 \%$ & $100 \%$ \\
\hline
\end{tabular}

Source: Own elaboration.

Table 5 shows that for $86.6 \%$ of surveyed firms, ISO 9001 was 'highly relevant' or 'extremely relevant' for external positive effects related to commercial aspects - that is to say, competition in the marketplace. The percentage of firms reporting that ISO 9001 was 'highly relevant' or 'extremely relevant' for external positive effects related to customer management was lower $(62.2 \%)$. Respondents gave the lowest score to the influence of ISO 9001 on external aspects related to finances (only $34.2 \%$ of respondents reported that ISO 9001 was 'highly relevant' or 'extremely relevant'). For all types of external effect, the percentage of firms choosing 'highly relevant' was notably higher than the percentage of firms choosing 'extremely relevant', except for commercial aspects, for which the percentage of firms choosing 'highly relevant' was the same as the percentage of firms choosing 'extremely relevant'.

After sorting the results for each positive effect (internal and external), it has been obtained the following ranking of benefits derived from implementing ISO 9001 in the Spanish construction sector, according to the responses of the participating firms:

Table 6

Ranking of the positive effects derived from implementing ISO 9001

\begin{tabular}{|c|c|c|}
\hline 范 & $\begin{array}{l}\text { Highly or extre- } \\
\text { mely relevant } \\
(\%)\end{array}$ & POSITIVE EFFECTS \\
\hline $1^{\mathrm{o}}$ & 86.6 & EXTERNAL COMMERCIAL EFFECTS \\
\hline $2^{\circ}$ & 74.4 & INTERNAL ORGANISATIONAL EFFECTS \\
\hline $3^{\circ}$ & 62.2 & EXTERNAL CUSTOMER MANAGEMENT EFFECTS \\
\hline
\end{tabular}




\begin{tabular}{|c|c|c|}
\hline $4^{\circ}$ & 53.7 & INTERNAL OPERATIONAL EFFECTS \\
\hline $5^{\circ}$ & 34.2 & EXTERNAL FINANCIAL EFFECTS \\
\hline $6^{\circ}$ & 31.7 & INTERNAL HUMAN RESOURCES MANAGEMENT EFFECTS \\
\hline
\end{tabular}

Source: Own elaboration.

Table 6 shows that implementing ISO 9001 was relevant for external benefits (both commercial benefits and human resources benefits) and internal benefits (in terms of both organisational processes and operations). Respondents placed a greater emphasis on the relevance of ISO 9001 in external benefits because the first and third places of the ranking were occupied by external positive effects. These results confirm hypothesis 1 because the implementation of ISO 9001 in the construction sector was found to yield both internal and external benefits in most cases.

\subsection{Influence of the size of Spanish construction firms and the time elapsed since obtaining ISO 9001}

The second aim of this study was to analyse whether the size of Spanish construction firms and the time elapsed since obtaining ISO 9001 influenced the standard's effects. First, they have been considered the segments by size, as per the criteria described in section 3 . The distribution appears in Table 2. Of the 126 participating firms, 10 were very large, 30 were large and 86 were medium sized.

Analysis of variance (ANOVA) was performed to observe the differences between each segment in terms of the positive effects derived from implementing ISO 9001 with respect to internal aspects (organisational processes, operations and human resources management) and external aspects (commercial, financial and customer management). The ANOVA tested whether the positive effects of implementing ISO 9001 differed significantly depending on the size of the firm (medium-sized, large and very large firms). Table 7 presents the results of this analysis.

Table 7

ANOVA of the benefits of implementing ISO 9001 by size of the firm

\begin{tabular}{|c|c|c|c|}
\hline Variables & Sig. & F & Mean squared \\
\hline Internal organisational effects & 0.906 & .099 & $\begin{array}{l}0.055 \text { Inter-group } \\
0.559 \text { Intra-group }\end{array}$ \\
\hline Internal operational effects & 0.977 & .023 & $\begin{array}{l}0.016 \text { Inter-group } \\
0.686 \text { Intra-group }\end{array}$ \\
\hline Internal human resources management effects & 0.290 & 1.259 & $\begin{array}{l}0.871 \text { Inter-group } \\
0.692 \text { Intra-group }\end{array}$ \\
\hline
\end{tabular}




\begin{tabular}{|c|c|c|c|}
\hline External commercial effects & 0.195 & 1.669 & $\begin{array}{l}1.087 \text { Inter-group } \\
0.651 \text { Intra-group }\end{array}$ \\
\hline External financial effects & 0.933 & .069 & $\begin{array}{l}0.073 \text { Inter-group } \\
1.055 \text { Intra-group }\end{array}$ \\
\hline External customer management effects & 0.809 & .212 & $\begin{array}{l}0.136 \text { Inter-group } \\
0.641 \text { Intra-group }\end{array}$ \\
\hline $\begin{array}{c}\text { p }<0.05 \text { significant at } 95 \% \\
\text { Factor: SIZE }\end{array}$ & & & \\
\hline
\end{tabular}

Source: Own elaboration.

The ANOVA for the internal positive effects (organisational, operational and human resources management) and external positive effects (commercial, financial and customer management) yielded significance levels that were greater than 0.05 , as did the F test and the mean squared (RMS). Hence, the ANOVA showed the absence of differences in behaviour depending on the size of Spanish construction firms that have implemented ISO 9001. The results of the ANOVA thereby confirm hypothesis 2 for all types of internal and external effect.

As regards the influence of the time elapsed since obtaining ISO 9001 on the positive effects derived from implementing the ISO 9001, Table 8 shows the responses of the participating firms.

Table 8

Relevance of the time elapsed since obtaining ISO 9001 on the standard's benefits

\begin{tabular}{|c|c|c|c|c|}
\hline Irrelevant & Slightly relevant & Moderately relevant & Highly relevant & $\begin{array}{c}\text { Extremely } \\
\text { relevant }\end{array}$ \\
\hline $2.5 \%$ & $4.8 \%$ & $31.2 \%$ & $39.8 \%$ & $21.7 \%$ \\
\hline
\end{tabular}

Source: Own elaboration.

Table 8 reveals a consensus regarding the positive influence of time since obtaining ISO 9001 on positive effects derived from the standard (only $7.3 \%$ of participating firms considered that the time elapsed was 'irrelevant' or 'slightly relevant'). To investigate this issue further, the 126 participating firms were classified into two groups according to whether the time elapsed since implementing ISO 9001 was greater than five years. Analysis of variance (ANOVA) was performed to observe the differences between each segment in terms of the positive effects derived from implementing ISO 9001 with respect to internal aspects (organisational processes, operations and human resources management) and external aspects (commercial, financial and customer management). The ANOVA tested whether the positive effects for Spanish construction firms implementing ISO 9001 differed significantly depending on the time elapsed since implementing ISO 9001 (more than five years vs. less than five years). Table 9 presents the results of this analysis. 
Table 9

ANOVA of the benefits of implementing ISO 9001 by time elapsed

\begin{tabular}{|c|c|c|c|}
\hline Variables & Sig. & F & Mean squared \\
\hline Internal organisational effects & 0.000 & 18.681 & $\begin{array}{c}\text { 8.376 Inter-group } \\
.448 \text { Intra-group }\end{array}$ \\
\hline Internal operational effects & 0.000 & 27.012 & $\begin{array}{c}13.680 \text { Inter-group } \\
.506 \text { Intra-group }\end{array}$ \\
\hline Internal human resources management effects & 0.001 & 11.501 & $\begin{array}{c}7.089 \text { Inter-group } \\
.616 \text { Intra-group }\end{array}$ \\
\hline External commercial effects & 0.104 & 1.490 & $\begin{array}{c}3.342 \text { Inter-group } \\
.605 \text { Intra-group }\end{array}$ \\
\hline External financial effects & 0.013 & 6.409 & $\begin{array}{c}6.195 \text { Inter-group } \\
.967 \text { Intra-group }\end{array}$ \\
\hline External customer management effects & 0.007 & 7.739 & $\begin{array}{c}4.488 \text { Inter-group } \\
.580 \text { Intra-group }\end{array}$ \\
\hline $\begin{array}{c}\text { p < 0.05 significant at 95\% } \\
\text { Factor: TIME ELAPSED }\end{array}$ & & & \\
\hline
\end{tabular}

Source: Own elaboration.

The ANOVA yielded significance levels that were less than 0.05 , as did the F test and the mean squared (RMS). Hence, the ANOVA showed the existence of differences in behaviour depending on the time elapsed since Spanish construction firms first implemented ISO 9001 (more than five years vs. less than five years). These differences were significant for all internal effects (organisational processes, operations and human resources management) and for the external effects related to finances and customer management. The ANOVA, however, revealed no significant differences for the external effects related to commercial aspects (i.e., meeting industry requirements to compete and enter new markets). Hence, the results of the ANOVA confirm hypothesis 3, except for the case of external effects related to commercial aspects. To make sense of the difference between the behavioural patterns in each group (more than five years vs. less than five years since obtaining ISO 9001), it has been calculated the mean score for each benefit under study, obtaining the results appearing in Table 10.

Table 10

Perceived mean benefit due to the implementation of the ISO 9001 by time elapsed

\begin{tabular}{|c|c|c|c|c|}
\hline \multirow{2}{*}{ Variables } & \multicolumn{2}{|c|}{ Time elapsed < 5 years } & \multicolumn{2}{c|}{ Time elapsed $\geq 5$ years } \\
\cline { 2 - 5 } & Mean & Std. Dev. & Mean & Std. Dev. \\
\hline Internal organisational effects & 3.38 & 0.752 & 4.07 & 0.628 \\
\hline Internal operational effects & 2.96 & 0.662 & 3.84 & 0.733 \\
\hline
\end{tabular}




\begin{tabular}{|c|c|c|c|c|}
\hline $\begin{array}{c}\text { Internal human resources manage- } \\
\text { ment effects }\end{array}$ & 2.65 & 0.797 & 3.29 & 0.780 \\
\hline External commercial effects & 3.88 & 0.952 & 3.93 & 0.684 \\
\hline External financial effects & 2.73 & 0.827 & 3.32 & 1.046 \\
\hline $\begin{array}{c}\text { External customer management } \\
\text { effects }\end{array}$ & 3.46 & 0.761 & 3.96 & 0.762 \\
\hline
\end{tabular}

Source: Own elaboration.

Table 10 shows that the mean of the perceived benefit was higher in the group of firms with a greater time elapsed since implementing ISO 9001 for all internal effects and for the external effects related to financial and customer management aspects. The difference for external effects related to commercial aspects (i.e., meeting requirements to compete and enter new markets) was negligible.

\section{CONCLUSIONS AND IMPLICATIONS}

\subsection{General conclusions}

The first aim of this study was to analyse the effects derived from the implementation of ISO 9001 in Spanish construction firms. Most Spanish construction firms considered that ISO 9001 enhanced internal effects because for two such effects (i.e., organisational improvements and improvements in the operations), significant percentages of firms $(74.4 \%$ and $53.7 \%$, respectively) reported that ISO 9001 was 'highly relevant' or 'extremely relevant'. For the effects related to 'human resources management', a lower percentage of firms $(31.7 \%)$ reported that ISO 9001 was 'highly relevant' or 'extremely relevant'. A possible explanation for this finding is that the pursuit of internal benefits due to quality is based more on the establishment of work procedures and controls than on human resources because of the large amount of subcontracting and the short-term nature of contracts in this sector.

Likewise, most firms reported that ISO 9001 enhanced external effects because for two such effects (i.e., commercial improvements and improvements in customer management), significant percentages of firms $(86.6 \%$ and $62.2 \%$, respectively) reported that ISO 9001 was 'highly relevant' or 'extremely relevant'. For the effects related to financial aspects, a lower percentage of firms (34.2\%) reported that ISO 9001 was 'highly relevant' or 'extremely relevant'. This finding may owe to the difficulty in accurately identifying the positive effects derived from implementing ISO 9001 in terms of the financial performance of the firm, as noted by Mann and Kehoe (1994).

The results of the analysis seem to be consistent with those of other authors mentioned in section (Escanciano et al. 2001; Gotzamani and Tsiotras 2002; Casadesús et al. 2004; Mercado et al. 2005; Rodriguez et al. 2006; Calisir 2007; Lo and Chang 2007; Zaramdini 2007; Feng et al. 2008; Jang and Lin 2008; Magd et al. 2010), who have reported that the effects of ISO 9001 may be internal and external. This finding is valid, regardless of the 
fact that the positive influence of implementing ISO 9001 was somewhat greater for external benefits, as demonstrated by the fact that the $1^{\text {st }}, 3^{\text {rd }}$ and $5^{\text {th }}$ positions of the ranking in Table 4 were occupied by external effects.

The second aim of this study was to analyse whether the size of Spanish construction firms and the time elapsed since obtaining ISO 9001 influenced the standard's effects. The ANOVA revealed an absence of significant differences by size of firm in terms of the positive effects derived from implementing ISO 9001. This conclusion seems to be consistent with the findings of certain studies cited in section 2 (Terziovski et al. 2003; Wilson et al. 2003; Briscoe et al. 2005; Bayati and Taghavi 2007; Lee et al. 2009; Psomas et al. 2010). These findings imply that regardless of their size, construction firms must meet the same standards in terms of the safety of their civil engineering projects and must have the corresponding certification to compete in public tenders.

In contrast, the results of the analysis seem to imply that the time elapsed since obtaining ISO 9001 positively influences the effects derived from the standard. Only $7.3 \%$ of firms reported that this factor was 'slightly relevant' or 'irrelevant'. Likewise, ANOVA revealed significant differences in positive effects depending on the time elapsed since obtaining ISO 9001 (more than five years vs. less than five years). The group of firms that had obtained ISO 9001 more than five years ago reported better results in practically all internal and external effects. This finding is consistent with studies cited in section 2 (Wilson et al. 2003; Climent 2005; Corbett et al. 2005; Terziovski and Power 2007; Martínez-Costa et al. 2008; Lo et al. 2009), suggesting that these benefits depend on genuinely implementing the basic principles of ISO 9001, a process that requires time. Only the positive effects related to external aspects of a commercial nature (i.e., meeting requirements to be able to compete and enter new markets) were less sensitive to the time elapsed since obtaining the standard. An explanation of this finding is that merely obtaining the ISO 9001 is sufficient to provide the firm with instant commercial benefits.

\subsection{Management implications}

The findings show that implementing ISO 9001 in the Spanish construction sector can, in most cases, yield positive internal and external effects. Furthermore, these effects are not influenced by the size of the firm and are positively influenced by the time elapsed since obtaining the standard.

Hence, managers of construction firms, regardless of their size, should consider implementing and/or maintaining ISO 9001 - accounting for the resulting financial and time costs - not only as a means of becoming eligible to compete in public tenders, but also as a way of actually improving the quality of the firm. Managers would thus improve the safety of their firms' civil engineering projects by eradicating errors and meeting deadlines, and would avoid the hefty fines imposed upon offending firms in this sector. Nevertheless, managers must be aware that these internal improvements in quality emerge gradually after the firm has implemented ISO 9001. 


\subsection{Limitations and future research opportunities}

This study's findings have limitations, which present opportunities for further research. First, this was a descriptive study, which did not analyse the causal relationship between the requirements of ISO 9001 and the potential benefits derived from obtaining this standard. Therefore, the findings must be interpreted with caution and should be considered approximations until new empirical studies have confirmed them. Second, respondents were heads of quality at the participating firms, so their opinions may be biased due to a desire to portray implementation of the ISO 9001 as having had a positive outcome. Third, the sampling error for this study was $6.7 \%$ (Table 3). It was therefore greater than 5\%, which represents a limitation when extrapolating the findings to the entire sector.

Future research should examine the causal relationships between the requirements and basic principles of the ISO 9001 and its potential benefits. In addition, to avoid any possible bias of the participants in favour of ISO 9001, as mentioned in the previous paragraph, it would be advisable to broaden the scope of the survey to include other stakeholders such as employees, customers and suppliers. Another interesting future research avenue would be to increase the sample size, drawing upon support from construction sector associations (SEOPAN, ANCI, AERCO, etc.) or quality management associations (AENOR, AEC, etc.). These new empirical studies could confirm the conclusions reported in this paper. Finally, although the findings show that most entities enjoyed benefits from implementing the ISO 9001, this was not universally true, particularly in the case of internal effects related to human resources management and external effects related to financial aspects. Therefore, future studies should explore the determinants that drive or hamper positive results derived from implementing ISO 9001 in the construction sector.

\section{REFERENCES}

Alic, M., 2014. Impact of ISO 9001 certification cancellation on business performance: a case study in Slovenian organisations. Total Quality Management and Business Excellence, 25 (7-8), 790-811.

Arana, G., Heras, I., Ochoa, C. and Andonegui, J., 2004. Incidencia de la Gestión de la Calidad en los Resultados de las Empresas: Un estudio de las Empresas Vascas. Revista de Dirección y Administración de Empresas, 11, 131-159.

Bayati, A. and Taghavi, A., 2007. The impacts of acquiring ISO 9000 certification on the performance of SMEs in Tehran. The TQM Magazine, 19 (2), 140-149.

Benner, M. and Veloso, F., 2008. ISO 9000 practices and financial performance: a technology coherence perspective. Journal of Operations Management, 26, 611-629.

Bhuiyan, N. and Alam, N., 2005. An investigation into issues related to the latest version of ISO 9000. Total Quality Management and Business Excellence, 8 (1), 28-42.

Boiral, O. and Amara, N., 2009. Paradoxes of ISO 9000 performance: a configurational approach. Quality Management Journal, 16, 36-60.

Briscoe, J., Fawcett, S. and Todd, R., 2005. The implementation and impact of ISO 9000 among small manufacturing enterprises. Journal of Small Business Management, 43 (3), 309-330. 
Calisir, F., 2007. Factors affecting service companies' satisfaction with ISO 9000. Managing Service Quality, 17 (5), 579-593.

Casadesus, M. and Heras, I., 2001. La Norma ISO 9000: beneficios de su introducción en las empresas españolas. Un estudio empírico. Revista Europea de Dirección y Economía de la Empresa, 10 (1), 55-67.

Casadesus, M., Karapetrovic, S. and Heras, I., 2004. Beneficios y costes de la implantación de la normativa de calidad ISO 9000: Un estudio comparativo (1998-2002). Revista de Economía y Empresa, 21 (51), 57-74.

Casadesus, M., Heras, I. and Marimon, F., 2011. Impact of quality improvements tools on the performance of firms using different quality management systems. Innovar Revista de Ciencias Administrativas y Sociales, 21 (42), 161-173.

Climent, S., 2005. Los costes, gastos, burocracia e incremento de productividad por la certificación en la norma ISO 9000 en las empresas certificadas en la norma ISO 9000 de la Comunidad Valenciana. Investigaciones Europeas de Dirección y Economía de la Empresa, 11(1), 245-259.

Corbett, C., Montes, M. and Kirsch, D., 2005. The Financial Impact of ISO 9000 Certification in the United States: An Empirical Analysis. Management Science, 51 (7), 1046-1059.

Criado, F. and Calvo, A., 2009. Factores clave y rendimiento en empresas españolas con sistemas de gestión de la calidad. Revista Europea de Dirección y Economía de la Empresa, 18 (2), 107-126.

Delic, M., Radlovacki, V., Kamberovic, B., Maksimovic, R. and Pecujlija, M., 2014. Examining relationships between quality management and organisational performance in transitional economies. Total Quality Management \& Business Excellence, 25 (3-4), 367-382.

Dick, G., Heras, I. and Casadesús, M., 2008. Shedding light on causation between ISO 9001 and improve business performance. International Journal of Operations and Production Management, 28 (7), 687-708.

Douglas, A., Coleman, S. and Oddy, R., 2003. The Case for ISO 9000. The TQM Magazine, 15 (5), 316-324.

Escanciano, C., Fernández, E. and Vázquez, C., 2001. ISO 9000 Certification and Quality Management in Spain: Results of a National Survey. The TQM Magazine, 13 (3), 192200.

Feng, M., Terziovski, M. and Samson, D., 2008. Relationship of ISO 9001:2000 quality certification with operational and business performance: a survey in Australia and New Zealand-based manufacturing and service companies. Journal of Manufacturing Technology Management, 19 (1), 22-37.

FLC: Fundación Laboral de la Construcción, 2002. Estudio del sector de la construcción.

Gotzamani, K. and Tsiotras, G., 2002. The true motives behind ISO 9000 certification. International Journal of Quality and Reliability Management, 19 (2), 151-169.

Gotzamani, K., Theodorakioglou, Y. and Tsiotras, G., 2006. A longitudinal study of the ISO 9000 (1994) series' contribution towards TQM in Greek industry. The TQM Magazine, $18(1), 44-54$. 
Gustafsson, R., Klefsjo, B., Berggren, E. and Granfors-Wellements, U., 2001. Experiences From Implementing ISO 9000 in Small Enterprises. A Study of Swedish Organizations. The TQM Magazine, 13 (4), 232-246.

Gutiérrez, L., Torres, I. and Molina, V., 2010. Quality management initiatives in Europe: An empirical analysis according to their structural elements. Total Quality Management \& Business Excellence, 21 (6), 577-601.

Heras, I., Dick, G. and Casadesus, M., 2002. ISO 9000 Registration's Impact on Sales and Profitability. International Journal of Quality and Reliability Management, 19 (6), 774-791.

Heras, I., Arana, G. and San Miguel, E., 2010. An Analysis of the Main Drivers for ISO 9001 and other Isomorphic Metastandards. Review of International Comparative Management, 11 (4), 562-574.

Heras, I, Casadesús, M. and Marimón, F., 2011. The impact of ISO 9001 standard and the EFQM model: The view of the assessors. Total Quality Management \& Business Excellence, 22 (2), 197-218.

ISO, 2013. The ISO Survey 2012. Geneve: ISO Editions.

Jang, W. and Lin, C., 2008. An integrated framework for ISO 9000 motivation, depth of ISO 9000 implementation and firm performance: the case of Taiwan. Journal of Manufacturing Technology Management, 19 (2), 194-216.

Karapetrovic, S., Casadesus, M. and Heras, I., 2010. What happened to the ISO 9000 lustre? An eight-year study. Total Quality Management \& Business Excellence 21 (3), 245-267.

Lee, P., To, W. and Yu, B., 2009. The implementation and performance outcomes of ISO 9000 in service organizations: an empirical taxonomy. International Journal of Quality and Reliability Management, 26 (7), 646-662.

Lo, C., Yeung, A. and Cheng, T., 2009. ISO 9000 and supply chain efficiency: Empirical evidence on inventory and account receivable days. International Journal of Production Economics, 118, 367-374.

Lo, L. and Chang, D., 2007. The difference in the perceived benefits between firms that maintain ISO certification and those that do not. International Journal of Production Research, 48 (5), 1881-1897

Magd, H., 2008. ISO 9001:2000 in the Egyptian manufacturing sector: Perceptions and

perspectives. International Journal of Quality \& Reliability Management, 25 (2), 173-200.

Magh, H., Khanna, H. and Sharma, D., 2010. ISO 9000: Implementation in Indian Manufacturing Organizations. Global Business and Management Research, 2 (4), 337-345.

Mann, R. and Kehoe, C., 1994. An evaluation of the effects of quality improvement activities on business performance. International Journal of Quality \& Reliability Management, 11, 29-44.

Martín, R. and González, J., 2011. Análisis Estratégico de la Industria de la Construcción en España. Cuadernos de Gestión, 11 (1), 141-161.

Martínez, L., Flores, E. and Martínez, J., 2010. Análisis de las necesidades del cliente y su satisfacción en la industria del mueble según las normas ISO 9000: un estudio de casos. Cuadernos de Gestión, 10 (2), 99-106.

Martínez, M., Rodríguez, N. and Vázquez, J., 2004. Incidencia de las certificaciones ISO 9000 en el sector gallego de la construcción. Forum de Calidad, 16 (156), 46-51. 
Martínez-Costa, M., and Martínez-Lorente, A., 2007. A triple analysis of ISO 9000 effects on company performance. International Journal of Productivity and Performance Management 56 (5), 484-499.

Martínez-Costa, M., Martínez-Lorente, A. and Choi, T., 2008. Simultaneous consideration of TQM and ISO 9000 on performance and motivation: An empirical study of Spanish companies. International Journal of Production Economics, 113 (1), 23-39.

Martinez-Costa, M., Choi, T., Martínez, J. and Martinez-Lorente A., 2009. ISO 9000/1994, ISO 9001/2000 and TQM: The performance debate revisited. Journal of Operations Management, 27, 495-511.

Melao, N. and Guia, S., 2013. Exploring the impacts of ISO 9001 on small- and mediumsized social service institutions: a multiple case study. Total Quality Management \& Business Excellence, 26 (3-4), 312-326.

Mercado, C., Castillo, C. and Mateo, A., 2005. La Normativa ISO 9000 como Herramienta para Incrementar el Valor Percibido por el Cliente en las Entidades Financieras Españolas, en González, F. and Terceño, A. (eds.), Simultaneidad Decisional y Multifocalidad Empresarial. A Coruña: AEDEM Ediciones.

Nicolau, J. and Sellers, R., 2003. Influencia de la calidad sobre la rentabilidad y la volatilidad. Revista de Economía Aplicada, 11, 65-82.

Nwankwo, S., 2000. Quality assurance in small business organisations: myths and realities. Internacional Journal of Quality \& ReliabilityManagement, 17 (1), 82-99.

Pires, A., Cociorva, A., Saraiva, M., Novas, J.C. y Rosa, A., 2013. Management of quality related costs: the case of Portuguese companies. Total Quality Management \& Business Excellence, 24(7-8), 782-796.

Psomas, E., 2013. The effectiveness of the ISO 9001 quality management system in service companies. Total Quality Management \& Business Excellence 24 (7), 769-781.

Psomas, E., Fotopoulos, C. and Kafetzopoulos, D., 2010. Critical Factors for Effective Implementation of ISO 9001 in SME Service Companies. Managing Service Quality, 20 (5), 440-457.

Rodriguez, J., Gonzalez, J. and Martínez, A., 2006. An analysis of the degree of small companies' dissatisfaction with ISO 9000 certification. Total Quality Management, 17 (4), 507-521.

Rusjan, B. and Alic, M., 2010. Capitalising on ISO 9001 benefits for strategic results. International Journal of Quality \& Reliability Management, 27(7), 756-778.

Sampaio, P., Saraiva, P. y Rodrigues, A., 2009. ISO 9001 certification research: questions, answers and approaches. International Journal of Quality and Reliability Management, 26 (1), 38-58.

Sampaio, P.; Saraiva, P. and Guimaraes, A., 2010. A Classification Model for Prediction of Certification Motivations from the Contents of ISO 9001 Audit Reports". Total Quality Management and Business Excellence, 21 (12), 1279-1298.

Seopan, 2012. Informe Económico 2011. Madrid: Seopan ediciones.

Sharma, D., 2005. The association between ISO 9000 certification and financial performance. International Journal of Accounting, 40 (2), 151-172.

Tari, J., Molina-Azorín, J. and Heras, I., 2012. Benefits of ISO 9001 and ISO 14001 standards: a literature review. Journal of Industrial Engineering Management, 5 (2), 297 332 . 
Terlaak, A. and King, A., 2006. The effect of certification with the ISO 9000 Quality Management Standard: A signalling approach. Journal of Economics Behavior \& Organization, 60 (4), 579-602.

Terziovski, M. and Power, D., 2007. Increasing ISO 9000 certification benefits: a continuous improvement approach. International Journal of Quality and Reliability Management, 24 (2), 141-163.

Terziovski, M., Power, D. and Sohal, A., 2003. The longitudinal effects of the ISO 9000 certification process on business performance. European Journal of Operational Research, 146 (3), 580-595.

Torres, E., 2009. Las grandes empresas constructoras españolas: crecimiento e internacionalización en la segunda mitad del siglo XX. Información Comercial Española, 849 (Julio-Agosto 2009), 113-127.

Vinuesa, L., 2007. La influencia de la certificación ISO 9000 sobre los resultados. Revista Iberoamericana de Contabilidad de Gestión, 10, 145-176

Wahid, R. and Corner, J., 2009. Critical success factors and improvements in ISO 9000 maintenance. International Journal of Quality \& Reliability Management, 26 (9), 881893.

Wayhan, V., Kirche, E. and Khumawala, B., 2002. ISO 9000 certification: The financial performance implications. Total Quality Management, 13, 217-231.

Wilson, J., Walsh, M., and Needy, K., 2003. An Examination of the Economic Benefits of ISO 9000 and the Baldrige Award. Engineering Management Journal, 18 (4), 431-443.

Williams, A., 2004. The impact of motivating factors on implementation of ISO 9001:2000 registration process. Management Research News, 27 (1/2), 74 - 84.

Zaramdini, W., 2007. An empirical study of the motives and benefits of ISO 9000 certification: The UAE experience. International Journal of Quality and Reliability Management, 24 (5), 472-491. 


\section{APPENDIX. QUESTIONNAIRE}

Details of the respondent and his or her firm.

Name

Surname

Telephone.

Fax

Email

Job description

Firm.

1. Indicate the number of people working at your firm at the end of the last financial year: employees.

2. Indicate the total turnover of your firm for the last financial year: Euros.

ISO 9001 STANDARD (Complete if this standard has been implemented)

1. Number of years since the standard was obtained:

- $\quad<5$ years.

- $\quad \geq 5$ years.

2. For which processes has the firm obtained the ISO 9001 standard?

- $\quad$ All processes within the firm.

- $\quad$ Only the processes related to some lines of business.

- $\quad$ Only the processes related to some operational areas.

3. How would you rate the effects resulting from implementing the ISO 9001 standard in your firm?

\section{I) INTERNAL EFFECTS}

a) Organisational effects

(Controlling production management, establishing rules and responsibilities, improving coordination with suppliers, increasing innovation, improving the IT systems for process management, improving internal controls for detecting nonconformities, etc.).

1) Irrelevant 2) Slightly relevant 3) Moderately relevant 4) Highly relevant 5) Extremely relevant b) Effects on operations 
(Better use of resources, reduction in inspection costs, improvements in general efficiency, reduction in logistics costs and production costs, reduction in nonconformities, improvements in meeting deadlines, reduction in expenses due to poor quality, etc.).

1) Irrelevant 2) Slightly relevant 3) Moderately relevant 4) Highly relevant 5) Extremely relevant

\section{c) Effects related to human resources}

(Improvements in employee feedback systems, participation in teams, reduction in worker absenteeism, greater satisfaction and motivation at work, etc.).

1) Irrelevant 2) Slightly relevant 3) Moderately relevant 4) Highly relevant 5) Extremely relevant

II) EXTERNAL EFFECTS

\section{a) Commercial effects}

(The requirement of obtaining ISO 9001 to compete in the sector and enter new markets).

1) Irrelevant 2) Slightly relevant 3) Moderately relevant 4) Highly relevant 5) Extremely relevant

\section{b) Financial effects}

(Increase in turnover and market share, improvements in turnover per employee, etc.).

1) Irrelevant 2) Slightly relevant 3) Moderately relevant 4) Highly relevant 5) Extremely relevant

\section{c) Client-related effects}

(Increase in the number of contracts from the same clients, reduction in nonconformities or complaints, improvements in satisfaction, improvements in market image, etc.).

1) Irrelevant 2) Slightly relevant 3) Moderately relevant 4) Highly relevant 5) Extremely relevant

4. How would you rate the influence of the time elapsed between obtaining the ISO 9001 standard and the appearance of the effects resulting from the standard?

1) Irrelevant 2) Slightly relevant 3) Moderately relevant 4) Highly relevant 5) Extremely relevant 
